\title{
CORRIGENDUM
}

Genes \& Development 34: 1227-1238 (2020)

\section{Corrigendum: In vivo CRISPR screening for phenotypic targets of the mir-35-42 family in C. elegans}

Bing Yang, Matthew Schwartz, and Katherine McJunkin

In the above-mentioned article, the sequence of the $d p y-10$ gRNA in Supplemental Table S1, cell D13, was incorrect. Also, the allele name for cex-2(cdb96) was incorrect in Supplemental Table S4, cell A12. These errors have been corrected in the Revised Supplemental Material online. The authors apologize for these errors.

doi: $10.1101 / \mathrm{gad} .349209 .121$ 


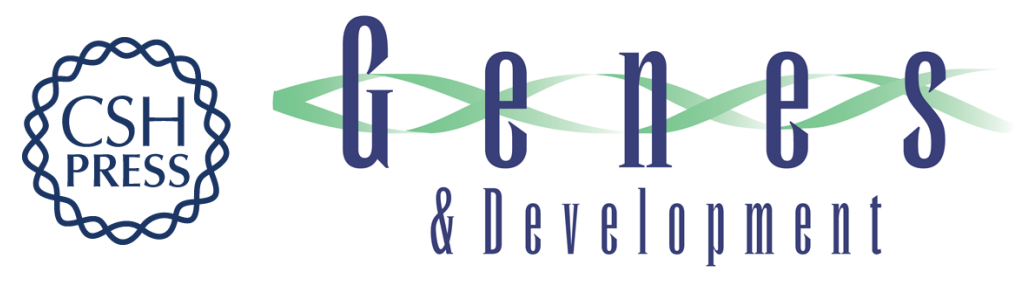

\section{Corrigendum: In vivo CRISPR screening for phenotypic targets of the mir-35-42 family in C. elegans}

Bing Yang, Matthew Schwartz and Katherine McJunkin

Genes Dev. 2021, 35:

Access the most recent version at doi:10.1101/gad.349209.121

\section{Related Content}

In vivo CRISPR screening for phenotypic targets of the mir-35-42 family in C. elegans

Bing Yang, Matthew Schwartz and Katherine McJunkin

Genes Dev. September , 2020 34: 1227-1238

\section{License}

Email Alerting

Receive free email alerts when new articles cite this article - sign up in the box at the top

Service right corner of the article or click here.

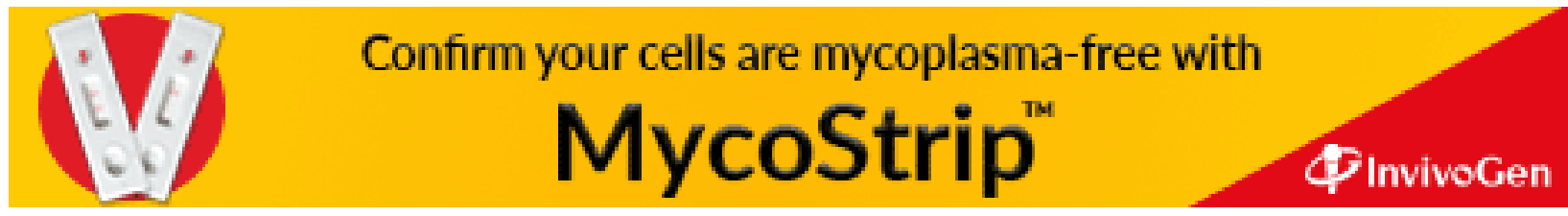

